\title{
IMPLEMENTASI PENGELOLAAN TENAGA PENDIDIK DI MI AZ-ZAHIR PALEMBANG
}

\author{
Rachmad Sobri \\ Magister FITK UIN Sunan Kalijaga Yogyakarta \\ rachmadsobri33@gmail.com
}

Received: 19/12/2018, Accepted: 23/01/2019, Published: 28/01/2019

\begin{abstract}
This research is entitled implementation of management of educators in MI Az-Zahir Palembang. With the formulation of the first problem: How is the Implementation of management of educators in Ml Az-Zahir Palembang? Second: what are the factors that support and hinder the Implementation of management of Educators in MI Az-Zahir Palembang? The purpose of this study was to find out how the implementation of management of teaching staff at MI Az-Zahir Palembang, to find out what factors support and hinder the implementation of management of mducators in Ml Az-Zahir Palembang. In the study the authors used qualitative research. The informants in this study were the principal of MI Az-Zahir Palembang as the key informant and head of the TU as well as educators as supporting informants. Sources of data in this study are primary data sources in the form of data obtained from the MI Az-Zahir Palembang principal and secondary data obtained from the literature relating to this study including the teaching staff documents. Data collection techniques through observation, interviews, were shown to the Ml Az-Zahir Palembang head of the TU head and educators and documentation were used to collect data on the state of the educator's environment etc. Data analysis techniques are done by data reduction, data presentation, and conclusions or data verification. The results showed that the implementation of teaching staff at $\mathrm{Ml} \mathrm{Az-Zahir} \mathrm{Palembang} \mathrm{from} \mathrm{the} \mathrm{process} \mathrm{of} \mathrm{planning,} \mathrm{recruitment,}$ selection, orientation, placement and evaluation of teaching staff was quite good. Because the school has carried out the planning process of the teaching staff until the evaluation of the teaching staff, the lack of supervision by the principal is still found by teaching staff not in science and there are still teachers who are only high school graduates, so the process of teaching educators is maximal. The factors that influence the implementation of educators are supporting and inhibiting factors. Supporting factors are the ability of a good headmaster, the competence of teaching staff in accordance with their scientific fields, complete facilities and infrastructure, adequate funding, and school committees that play an active role. Whereas the inhibiting factors for the implementation of teaching staff are the inability of principals to manage educators, the competence of educators who are not in accordance with their knowledge and school needs, incomplete facilities and infrastructure, lack of community participation in the management of educators, and financial financing management. not maximal.
\end{abstract}

Keyword: implementation of management, teaching staff. 


\begin{abstract}
ABSTRAK
Penelitian ini berjudul implementasi pengelolaan tenaga pendidik di MI AzZahir Palembang. Dengan rumusan masalah pertama: Bagaimana implementasi pengelolaan tenaga pendidik di MI Az-Zahir Palembang? Kedua: Apa saja faktor yang mendukung dan menghambat Implementasi Pengelolaan Tenaga Pendidik di MI Az-Zahir Palembang? Adapun tujuan dari penelitian ini adalah untuk mengetahui bagaimana implementasi pengelolaan tenaga pendidik di MI Az-Zahir Palembang, Untuk mengetahui apa saja faktor yang mendukung dan menghambat implementasi Pengelolaan Tenaga Pendidik di MI Az-Zahir Palembang. Dalam penelitian penulis menggunakan penelitian kualitatif. Informan dalam penelitian ini yaitu kepala sekolah MI Az-Zahir Palembang sebagai key informan dan kepala TU serta tenaga pendidik sebagai informan pendukung. Sumber data dalam penelitian ini adalah sumber data primer berupa data yang diperoleh dari kepala sekolah MI Az-Zahir Palembang dan data sekunder diperoleh dari literatur yang berkaitan dengan penelitian ini termasuk dokumen tenaga pendidik. Teknik pengumpulan data melalui observasi, wawancara, ditujukan kepada kepala sekolah MI Az-Zahir Palembang, kepala TU serta tenaga pendidik dan dokumentasi digunakan untuk menghimpun data tentang keadaan tenaga pendidik dan lain-lain. Teknik analisis data dilakukan dengan reduksi data, penyajian data, dan kesimpulan atau verifikasi data. Hasil penelitian menunjukan bahwa Implementasi tenaga pendidik di MI Az-Zahir Palembang dari proses perencanaan, rekrutmen, seleksi, orientasi, penempatan, dan evaluasi tenaga pendidik sudah cukup baik. Karena sekolah telah melakukan proses perencanaan tenaga pendidik sampai evaluasi tenaga pendidik, namun kurangnya pengawasan yang dilakukan kepala sekolah masih ditemukan tenaga pendidik yang mengajar bukan pada keilmuannya serta masih ada guru yang hanya tamatan SMA, sehingga proses implementasi tenaga pendidik belum maksimal. Adapun faktor-faktor yang mempengaruhi implementasi tenaga pendidik berupa faktor pendukung dan penghambat. Faktor pendukung, yaitu kemampuan kepala sekolah yang baik, kompetensi tenaga pendidik yang sesuai dengan bidang keilmuannya, sarana dan prasarana yang lengkap, pembiayaan yang memadai, dan komite sekolah yang berperan aktif. Sedangkan faktor penghambat implementasi tenaga pendidik, yaitu kurang mampunya kepala sekolah dalam melakukan pengelolaan tenaga pendidik, kompetensi tenaga pendidik yang tidak sesuai dengan keilmuannya dan kebutuhan sekolah, sarana dan prasarana yang belum lengkap, kurangnya peran serta masyarakat dalam pengelolaan tenaga pendidik, dan pengelolaan pembiayaan keuangan yang belum maksimal.
\end{abstract}




\section{A. PENDAHULUAN}

Sarwoto

(2000:

mengungkapkan bahwa di era globalisasi seperti saat ini pengelolaan tenaga pendidik dan kependidikan memegang peranan yang sangat penting dalam upaya pembentukan karakter bangsa serta peningkatan kualitas SDM (sumber daya manusia) mengingat persaingan di era sekarang semakin ketat dikarenakan pesatnya kemajuan ilmu pengetahuan dan teknologi, sehingga dibutuhkan suatu mekanisme pengelolaan yang baik bagi tenaga pendidik dan kependidikan.

Pengelolaan tenaga pendidik dimulai dari proses penerimaan tenaga pendidik dari awal proses penyeleksian tenaga pendidik sampai evaluasi tenaga pendidik atas hasil kinerja dan kompetensi tenaga pendidik. Pengelolaan tenaga pendidik sangat perlu dilakukan karena berfungsi untuk sistem manajerial, mengembangkan potensi tenaga pendidik, serta meningkatkan kinerja tenaga pendidik sesuai dengan bidang keilmuan dan keahliannya (Sarwoto, 2000: 148).

Sehingga menciptakan tenagatenaga pendidik yang handal di bidangnya atau sesuai dengan keilmuannya, serta demi terselenggaranya pendidikan yang efektif dan efesien dengan dilakukannya pengelolaan tenaga pendidik secara baik dan benar. Jika pengelolaan tenaga pendidik dilakukan secara tepat maka akan mampu meningkatkan kinerja pendidik itu sendiri dalam menjalankan tugasnya serta dapat menyalurkan ilmu yang ia punya secara maksimal.

Tenaga pendidik yang dimaksud ialah guru, guru merupakan profesi atau pekerjaan yang memerlukan keahlian khusus sebagai guru, jenis pekerjaan ini tidak dapat dilakukan sembarang orang di luar bidang kependidikan. Adapun syarat untuk menjadi guru tertuang dalam Undangundang No. 20 tahun 2003 dan Peraturan Pemerintah RI No. 19 Tahun 2005 Bab VI tentang Standar Pendidik dan Tenaga Kependidikan memuat persyaratan menjadi guru seperti yang dimuat pada Pasal 28 , yaitu: (1) guru harus memiliki kualifikasi akademik dan kompetensi sebagai agen pembelajaran, sehat jasmani dan rohani, serta memiliki kemampuan untuk mewujudkan tujuan pendidikan nasional. (2) kualifikasi akademik sebagaimana dimaksud pada ayat 1 tingkat pendidikan minimal yang harus dipenuhi oleh seorang 
guru yang dibuktikan dengan ijazah atau sertifikat keahlian yang relevan sesuai dengan ketentuan perundangundangan yang berlaku. (3) memiliki kompetensi meliputi: kompetensi pedagogik, kepribadian, profesional, dan sosial (Ramayulis, 2013: 5).

Pengelolaan tenaga pendidik masih kurang maksimal, hal ini dikarenakan oleh sumber daya manusia yang masih kurang bersaing dengan pasar global yang mempunyai kompetensi dan skill yang baik. Sedangkan dalam tujuan pendidikan Indonesia pengelolaan sumber daya manusia harus mampu bersaing dan mempunyai kompetensi yang baik sehingga tujan pendidikan yang telah ditetapkan dapat tercapai. Dari pengelolaan tenaga pendidik yang baik maka tujuan pendidikan dapat dioptimalkan sebagaimana mestinya. Pendidikan yang baik bermula pada pengelolaan yang baik juga sesuai dengan kebutuhannya, dimana salah satu faktor penunjang keberhasilan pendidikan salah satunya terletak pada pengelolan tenaga pendidik yang dikelola secara baik dan maksimal. Dalam pandangan Islam tenaga pendidik atau guru mempunyai tugas mengajarkan hal-hal kebaikan yang dapat diterapkan di kehidupan seharihari, sebagaimana yang dijelaskan dalam Al-Qur'an Surah Al-Baqarah Ayat 129.

Pengelolaan tenaga pendidik seharusnya melakukan proses pengelolaan tenaga pendidik sesuai dengan kebutuhan dan tujuan pendidikan itu sendiri. Banyak sekolah yang melakukan pengelolaan tenaga pendidik tidak sesuai dengan kebutuhan, salah satu bentuk pengelolaan tenaga pendidik yang tidak sesuai pengelolaan pada proses seleksi dan penempatan tenaga pendidik dimana pada proses ini seharusnya tenaga pendidik harus memenuhi syarat-syarat menjadi guru sesuai dengan UUD yang telah dijelaskan di atas, baik dari tahap seleksi hinga tahap pengevaluasian tenaga pendidik. Seharusnya tenaga pendidik ditempatkan sesuai dengan keilmuan, kompetensi, serta bakat dan minat mengajarnya, sehingga tenaga pendidik dapat bekerja sesuai dengan arahan dan ilmu yang ia punya. Sehingga proses belajar mengajar dapat berjalan dengan efektif dan efesien.

Dari hasil observasi awal di MI AzZahir Palembang proses pengelolaan tenaga pendidik dari awal perekrutan, seleksi, penempatan, dan evaluasi tenaga pendidik masih kurang maksimal, hal ini dibuktikan dengan 
syarat-syarat menjadi tenaga pendidik atau guru yang tertuang dalam undang-undang tidak sesuai dengan penerapannya. Sehingga pengelolaan tenaga pendidik, dari awal perencanaan sampai evaluasi tenaga pendidik dilakukan secara tertutup tanpa melihat kompetensi dan kemampuan terlebih dahulu terutama latar belakang keilmuan sehingga setelah diseleksi dan dilakukan penempatan tenaga pendidik, dimana hasilnya tenaga pendidik yang mengajar banyak yang tidak sesuai dengan latar belakang pendidikannya serta ilmu yang didalaminya. Misalnya guru yang mempunyai latar belakang pendidikan ekonomi mengajar olahraga dan guru yang mempunyai latar belakang pendidikan bahasa Indonesia mengajar geografi dan sebagainya.

Oleh karena itu, masih kurang efektifnya proses pengelolaan tenaga pendidik, dimana pengelolaan yang baik harus di mulai dari perencanaan sampai evaluasi tenaga pendidik yang baik pula sehingga tercapainya tujuan dari pendidikan itu sendiri. Dimana keberhasilan dalam pendidikan di mulai dari proses pengelolaan yang baik dalam hal ini tenaga pendidik yang merupakan tenaga/orang yang melaksanakan serta menyampaikan pembelajaran sesuai tujuan pembelajaran yang telah ditetapkan, jika dari pengelolaan tenaga pendidik saja tidak dilakukan dengan baik, bagaimana tujuan pendidikan akan bisa sampai pada hasil yang diinginkan.

Melihat dari permasalahan tersebut peneliti mengangkat judul “Implementasi Pengelolaan Tenaga Pendidik di Madrasah Ibtidaiyah (MI) Az-Zahir Palembang".

\section{B. TUJUAN DAN KEGUNAAN PENELITIAN}

1. Untuk mengetahui bagaimana implementasi pengelolaan tenaga pendidik di MI Az-Zahir Palembang.

2. Untuk mengetahui apa saja faktor yang mendukung dan menghambat implementasi Pengelolaan Tenaga Pendidik di MI Az-Zahir Palembang.

Adapun manfaat dalam penelitian ini sebagai berikut:

1. Secara teoritis adalah untuk mendeskripsikan pengelolaan tenaga pendidik yang dilakukan di Ml Az-Zahir Palembang, sehingga menjadi bahan kajian tentang penempatan tenaga pendidik di MI Az-Zahir Palembang. 
2. Secara praktis adalah dapat dijadikan salah satu sumbangan pemikiran bagi peningkatan mutu sekolah dan penentu kebijakan yang berkaitan dengan seleksi dan penempatan tenaga pendidik pada umumnya.

\section{METODE PENELITIAN}

\section{Pendekatan Penelitian}

Pendekatan penelitian yang digunakan oleh peneliti adalah pendekatan kualitatif. Pendekatan kualitatif merupakan analisis data yang dipergunakan untuk permintaan informasi yang bersifat menerangkan dalam bantuan deskriptif atau uraian. Pendekatan kualitatif lebih menekankan analisisnya pada proses penyimpulan deduktif dan induktif serta analisis terhadap dinamika hubungan antar fenomena yang diamati, dengan menggunakan logika ilmiah (Syaifuddin Azwar, 1998: 5). Proses penelitian yang digunakan pun berdasarkan teori yang relevan dengan permasalahan yang diteliti untuk menemukan solusi dalam permasalahan tersebut. Alasan memilih pendekatan kualitatif, karena hal ini berkaitan dengan konsep judul dan rumusan masalah yang dikemukakan pada pendahuluan yang mengarah pada studi kasus.
Dalam penelitian kualitatif, Creswell sebagaimana yang dikutip oleh Sugiyono menyatakan bahwa penelitian kualitatif berarti proses eksplorasi dan memahami makna perilaku individu dan kelompok, menggambarkan masalah sosial atau masalah kemanusiaan. Proses penelitian mencakup membuat pertanyaan penelitian dan prosedur yang masih bersifat sementara, mengumpulkan data pada seting partisipan, analisis data secara induktif, membangun data yang persial ke dalam tema dan selanjutnya memberikan interpretasi terhadap makna suatu data. Kegiatan akhir adalah membuat laporan ke dalam struktur yang fleksibel (Sugiyono, 2013: 228).

Metode penelitian kualitatif adalah metode penelitian yang berlandaskan pada filsafat postpositivisme (interpretif), digunakan untuk meneliti pada kondisi objek yang alamiah (natural setting) dimana peneliti adalah sebagai instrumen kunci, teknik pengumpulan data dilakukan secara triangulasi (gabungan), analisis data bersifat induktif/kualitatif dan hasil penelitian kualitatif lebih menekankan makna daripada generalisasi serta mampu menemukan hipotesis yang bersifat struktural/konstruktif. 


\section{Jenis Data dan Sumber Data}

a. Jenis data

Jenis data yang diambil adalah kualitatif yaitu data yang meliputi biografi sekolah, riwayat pendidikan tenaga pendidik, (kompetensi yang dimiliki tenaga pendidik), dan jumlah tenaga pendidik.

b. Sumber data

Data yang diperlukan peneliti bersumber dari:

1) Sumber data primer, yaitu data yang bersumber dari lapangan penelitian, khususnya tenaga pendidik dan kepala sekolah di MI Az-Zahir Palembang.

2) Sumber data sekunder, yaitu sumber penunjang yang diperoleh dari buku-buku yang dijadikan literatur dalam penelitian ini.

\section{Teknik Pengumpulan Data}

Dalam penelitian kualitatif, pengumpulan data dilakukan pada natural setting (kondisi alamiah), sumber data primer dan teknik pengumpulan data lebih banyak pada peran serta (participan obervasion), wawancara mendalam, dan dokumentasi (Sugiyono, 2010: 225). Data tersebut akan penulis ambil dari berbagai macam sumber baik membahas topik penelitian ini secara langsung maupun tidak langsung. Untuk memperoleh data-data yang diperlukan dalam penelitian ini penulis menggunakan metode sebagai berikut:

a. Observasi

Observasi merupakan metode pengumpulan data yang menggunakan pengamatan terhadap objek penelitian. Observasi dilakukan secara langsung maupun tidak langsung (Yatim, Ryanto, Op.Cit. 96). Metode ini digunakan untuk mengamati sistem perencanaan tenaga pendidik, penempatan tenaga pendidik, evaluasi tenaga pendidik, dan lainnya yang terdapat di MI Az-Zahir Palembang.

b. Dokumentasi

Metode dokumentasi berarti cara mengumpulkan data dengan mencatat data-data sudah ada. Dalam menggunakan instrumen dokumentasi ini, biasanya peneliti membuat instrumen dokumentasi yang berisi instansi variabelvariabel yang sudah ditentukan tadi dan nantinya tinggal membutuhkan tanda cek ditempat yang sesuai (Yatim Ryanto. Op.Cit. 103). Adapun metode ini digunakan untuk 
mengetahui data-data berkenaan dengan monografi sekolah, kompetensi yang dimiliki tenaga pendidik, yang bersifat arsip atau dokumen sesuai masalah yang dibahas. Dokumentasi yang diambil berupa jumlah tenaga pendidik, latar belakang pendidikan tenaga pendidik, dan data yang menunjang lainnya.

c. Wawancara

Wawancara merupakan metode pengumpulan data yang menghendaki komunikasi langsung antara penyelidik dengan subjek atau responden. Dalam interview biasanya terjadi tanya jawab sepihak yang dilakukan secara sistematis, dan berpijak pada tujuan penelitian (Yatim Ryanto. Op.Cit. 82). Metode ini digunakan untuk mengetahui kualitas tenaga pendidik serta faktor yang mempengaruhi penempatan tenaga pendidik. Yang menjadi informant wawancara adalah kepala sekolah, kepala administrasi, dan tenaga pendidik di MI Az-Zahir Palembang.

\section{Teknik Analisis Data}

Analisis data merupakan proses yang sangat penting dalam proses penelitian. Karena melalui analisis data inilah maka data akan nampak manfaatnya terutama dalam memecahkan suatu permasalahan dalam penelitian. Analisis data adalah proses mencari dan menyusun secara sistematis data yang diperoleh dari hasil wawancara, catatan lapangan, dan dokumentasi dengan cara mengorganisasikan data ke dalam kategori, menjabarkan ke dalam unitunit, melakukan sintesa, menyusun ke dalam pola, memilih nama yang penting dan yang akan dipelajari, dan membuat kesimpulan sehingga mudah di pahami oleh diri sendiri maupun orang lain.

Dalam penelitian ini peneliti melakukan teknik analisis data dengan menggunakan analisis kualitatif yang berupa informasi, uraian dalam bentuk bahasa prosa yang kemudian dikaitkan dengan data lainnya untuk mendapatkan kejelasan terhadap suatu kebenaran sehingga memperoleh gambaran baru atau gambaran yang dapat menguatkan gambaran yang ada. Dalam rangka menjawab perumusan masalah yang ditetapkan penulis, maka analisis data yang menjadi acuan dalam penelitian ini mengacu pada beberapa tahapan yang dijelaskan oleh Miles dan Huberman sebagaimana yang dikutip 
oleh Adnan Mahdi dan Mujahidin yang terdiri dari beberapa tahapan yaitu:

a. Pengumpulan informasi melalui wawancara terhadap key informan yang compatible terhadap penelitian kemudian observasi langsung di lapangan untuk menunjang penelitian yang dilakukan agar mendapatkan sumber data yang diharapkan.

b. Reduksi data yaitu proses pemilihan, pemusatan perhatian pada penyederhanaan, transformasi data kasar yang muncul dari catatan-catatan di lapangan selama meneliti. Tujuan diadakan transkrip data (transformasi data) untuk memilih informasi mana yang dianggap sesuai dengan masalah yang menjadi pusat penelitian di lapangan.

c. Penyajian data (data display) yaitu kegiatan sekumpulan informasi dalam bentuk teks naratif, grafik jaringan, tabel dan bagan yang bertujuan mempertajam pemahaman penelitian terhadap informasi yang dipilih kemudian disajikan dalam tabel ataupun uraian penjelasan. Namun yang akan paling sering digunakan untuk penyajian data penelitian kualitatif adalah teks yang bersifat naratif.

d. Pada tahap akhir adalah penarikan kesimpulan atau verifikasi, yang mencari arti polapola penjelasan, konfigurasi yang mungkin, alur sebab akibat dan proposisi. Penarikan kesimpulan dilakukan secara cermat dengan melakukan verifikasi berupa tinjauan ulang pada catatancatatan di lapangan sehingga data-data teruji validasinya (Adnan Mahdi dan Mujahidin, 2014: 137).

Tujuan dari analisis adalah untuk mengorganisasi deskripsi dengan cara membuatnya dapat dikendalikan. Deskripsi dapat diimbangi oleh analisis dan antaran ke dalam interprestasi. Suatu perhitungan final yang menarik dan mudah dibaca akan melengkapi deskripsi yang cukup untuk membantu pembaca memahami interprestasi dan penjelasan yang dipresentasikan (Emzir, 2011: 175-176).

\section{HASIL DAN PEMBAHASAN PENELITIAN}

\section{Perencanaan tenaga pendidik}

Perencanaan manajemen tenaga pendidik adalah pengembangan dan strategi dan penyusunan tenaga pendidik (Sumber Daya 
Manusia/SDM) yang komprehensif guna memenuhi kebutuhan organisasi di masa depan. Perencanaan SDM merupakan dari pelaksanaan fungsi manajemen SDM. Walaupun merupakan awal dari pelaksanaan fungsi manajemen Sumber Daya Manusia walaupun merupakan langkah awal yang harus dilaksanakan, perencanaan ini sering kali tidak diperhatikan dengan seksama. Dengan melakukan perencanaan ini, segala fungsi SDM dapat dilaksanakan dengan efektif dan efisien (Sondang P. Siagian, 2013: 154).

Perencanaan tenaga pendidik merupakan bagian dari proses pengelolaan tenaga pendidik dimana proses perencanaan ini menjadi langkah awal dalam menentukan tujuan pendidikan yang telah ditetapkan oleh sekolah. Proses perencanaan tenaga pendidik merupakan bagian dari fungsi manajemen sehingga jika perencanaan dilakukan secara efektif dan efesien maka proses pendidikan yang telah ditetapkan dapat terwujud. Berdasarkan hasil wawancara peneliti dengan kepala sekolah mengungkapkan bahwa:

"Dengan membuat pengumumannya di loker melalui FB. Pelamar harus menyerahkan lamaran kerja ke sekolah MI Az-Zahir. Melihat pengalaman kerjanya, latar belakang pendidikan dan kemampuan. Baru di saring untuk seterusnya menerima tenaga pendidik."

Adapun hasil wawancara yang dilakukan peneliti terhadap kepala tata usaha di Ml Az-Zahir palembang tentang proses perencanaan tenaga pendidik mengungkapkan bahwa:

"Proses perencanaan tenaga
pendidik dilakukan oleh kepala
sekolah dan yayasan sesuai
dengan kebutuhan baik dari segi
jumlah maupun kualitas tenaga
pendidik. Dengan membuka
lowongan kerja."

Berdasarkan kedua hal yang telah dikemukakan oleh kepala sekolah dan kepala tata usaha proses perencanaan tenaga pendidik di Madrasah Ibtidaiyah (MI) Az-Zahir Palembang dilakukan oleh kepala sekolah dengan membuat pengumuman melalui website FB sekolah MI Az-Zahir. Proses perencanaan tenaga pendidik juga melihat dari segi jumlah serta kualitas tenaga pendidik dalam proses perencanaan yang dilakukan oleh kepala sekolah. Dalam proses perencanaan tenaga pendidik di $\mathrm{MI} \mathrm{Az}$ Zahir Palembang terdapat orang-orang 
yang terlibat dalam proses perencanaan, adapun hasil wawancara yang dilakukan terhadap kepala sekolah mengungkapkan bahwa:

"Tentu saja saya sebagai Kepala sekolah, melibatkan guru komite sekolah, dan yayasan dalam proses perencanaan tenaga pendidik."

Adapun waktu yang ditentukan dalam proses perencanaan tenaga pendidik seperti yang dikemukan kepala tata usaha MI Az-Zahir Palembang mengungkapkan bahwa:

"Pada saat Tahun ajaran baru.

Dimana sekolah membutuhkan tenaga pendidik baru untuk mengajar di sekolah."

Berdasarkan porses perencanaan tenaga pendidik di MI Az-Zahir Palembang baik dari awal perencanaan tenaga pendidik yang melibatkan kepala sekolah, guru, komite sekolah dan yayasan serta waktu perencanaan tenaga pendidik dilakukan pada tahun ajaran baru dimana sekolah membutuhkan tenaga pendidik baru.

Adapun hasil observasi yang dilakukan peneliti di sekolah tentang proses perencanaan tenaga pendidik sebagai berikut: "hasil pengamatan peneliti saat menjadi mahasiswa magang yang dilakukan sejak bulan Agustus sampai bulan awal bulan November proses perencanaan tenaga pendidik dalam hal ini kepala sekolah melakukan perencanaan dengan mengadakan rapat guru pada awal tahun ajaran baru guna menetapkan tenaga pendidik yang baru yang akan direkrut. Kemudian barulah hasil dari rapat tersebut dipublikasikan dengan membuka lowongan pekerja bagi tenaga pendidik melalui website FB sekolah." (Hasil observasi)

Dari hasil yang telah dijelaskan di atas, peneliti dapat menganalisis bahwa proses perencanaan yang dilakukan sekolah sepenuhnya dilakukan oleh kepala sekolah melibatkan peran serta guru, kepala yayasan dan komite sekolah dalam menyusun rencana tenaga pendidik, yang dilakukan setiap tahun ajaran baru dimana sekolah membutuhkan tenaga pendidik baru.

Selain itu, proses perencanaan yang dilakukan sekolah juga memperhatikan berbagai macam aspek seperti jumlah tenaga pendidik yang dibutuhkan serta kualitas tenaga pendidik yang harus strata 1 (S1), 
barulah sekolah melakukan pemberitaan bahwa sekolah akan menerima tenaga pendidik yang baru melalui website Facebook sekolah.

\section{Rekrutmen Tenaga Pendidik}

Rekrutmen diartikan sebagai pencarian dan pengadaan calon sumber daya manusia yang berkualitas dan potensial, sehingga dapat diseleksi orang-orang yang paling tepat bagi kebutuhan kerja yang ada. Rekrutmen merupakan proses yang menghasilkan sejumlah pelamar yang mempunyai klasifikasi sesuai dengan tujuan organisasi. Dalam lingkup pendidikan, rekrutmen sumber daya manusia lebih banyak difokuskan pada pengadaan guru di sekolah (Nurul Ulfatin, 2016: 53-54).

Dalam proses pengelolaan tenaga pendidik setelah proses perencanaan dilakukan maka tahap selanjutnya adalah rekrutmen tenaga pendidik. Rekrutmen tenaga pendidik merupakan tahap atau bagian dari proses pengelolaan tenaga pendidik dimana rekrutmen dilakukan sebagai suatu usaha mencari pegawai baru sesuai kebutuhan serta dikarenakan pegawai lama atau guru ada yang berhenti, mutasi dan pensiun maka proses rekrutmen perlu dilakukan. Berdasarkan hasil wawancara yang dilakukan kepada sekolah bagaimana proses rekrutmen tenaga pendidik di sekolah mengungkapkan bahwa:

“Tenaga pendidik di Mi Az-Zahir ada yang tetap bertahan untuk menjadi pendidik, di setiap ajaran baru kemungkinan karena turut suami dan mungkin ada pekerjaan yang lebih baik dan jadi PNS saat itu lah Mi Az-Zahir memproses rekrutmen tenaga pendidik yang baru dengan membuka loker di fb." Adapun proses rekrutmen tenaga pendidik di sekolah seperti yang disampaikan oleh salah satu guru melalui wawancara mengungkapkan bahwa:

"Proses rekrutmen yang dilakukan biasanya terdapat kekosongan tenga pendidik ada yang pindah ada juga yang pensiun maka dari itu rekrutmen dilakukan tergantung kebutuhan sekolah kemudian tergantung kualitas guru yang dibutuhkan."

Berdasarkan apa yang telah disampaikan dalam wawancara di atas maka proses perekrutan tenaga pendidik di MI Az-Zahir dilakukan pada saat terjadinya kekosongan tenaga pendidik baik dikarenakan adanya guru yang pindah tugas karena faktor keluarga, karena berhenti atau mengundurkan diri serta ada guru 
lama yang pensiun. Barulah proses rekrutmen dilakukan untuk mengisi kekosongan tenaga pendidik. Biasanya dalam proses rekrutmen dilakukan pada saat awal tahun ajaran baru sesuai dengan kriteria tenaga pendidik yang dibutuhkan oleh sekolah. Dalam proses rekrutmen tenaga pendidik, sekolah mempunyai persyaratan dalam melakukan rekrutmen, seperti yang diungkapkan oleh kepala sekolah dalam hasil wawancara mengatakan bahwa:

"Syarat dalam rekrutmen tenaga pendidik pelamar harus S1, Islam, sopan dan santun, tidak menuntut gaji yang lebih, tidak terlibat narkoba serta tidak terlibat tindak pidana."

Adapun hasil wawancara lainnya yang dilakukan terhadap guru mengenai persyaratan rekrutmen tenaga pendidik mengungkapkan bahwa:

"Harus memiliki ijazah S1 kemudian memiliki pengalaman mengajar dan harus berkelakuan baik yang sudah sudah seperti itu."

Dari hasil wawancara di atas mengenai proses rekrutmen penulis menganalisis bahwa rekrutmen yang dilakukan oleh sekolah pada saat sekolah kekurangan tenaga pendidik seperti berhentinya tenaga pendidik, karena telah mendapatkan pekerjaan yang jauh lebih menjanjikan, adanya mutasi yang dipengaruhi faktor keluarga serta pensiunnya tenaga pendidik. Baru proses rekrutmen tenaga pendidik dilakukan oleh pihak sekolah dalam hal ini kepala sekolah yang melakukan proses rekrutmen. Adapun syarat-syarat dalam rekrutmen yang ditentukan oleh sekolah seperti harus memiliki ijazah strata 1 (S1), beragama Islam, sopan dan tidak terlibat dalam kasus kriminalitas, baru lah jika syarat rekrutmen ini dipenuhi sekolah bisa melakukan tahap selanjutnya yang dilakukan oleh kepala sekolah, namun kenyataan dilapangan masih terdapat 3 orang guru yang masih belatar pendidikan SMA ini dibuktikan dari hasil dokumentasi yang didapat peneliti sehingga proses rekrutmen di sekolah masih ada kurang berjalan dengan semestinya.

\section{Seleksi tenaga pendidik}

Seleksi merupakan proses di mana organisasi-organisasi memutuskan orang yang akan atau tidak akan diizinkan masuk ke organisasi-organisasi.

Beberapa standar umum harus dipenuhi pada proses seleksi apapun: keandalan (reability), kebahasaan, generalisasi, 
pemanfaatan dan legalitas (Nurul Ulfatin, 2016: 19-30). Seleksi tenaga pendidik merupakan bagian dari proses pengelolaan dimana setelah dilakukan proses perencanaan, rekrutmen barulah masuk ke dalam tahap seleksi tenaga pendidik. Seleksi tenaga pendidik merupakan tahap dimana seseorang atau tenaga pendidik baru akan diterima atau tidak di dalam suatu organisasi khususnya sekolah. Adapun teknis seleksi tenaga pendidik sebelum diputuskan diterima atau tidaknya dalam suatu organisasi/sekolah, sebagaimana yang diungkapkan oleh kepala sekolah dalam proses wawancara mengungkapkan bahwa:

"Setiap yang ingin melamar harus orang yang bersangkutan datang ke sekolah dengan membawa berkas lamaran, karena pada saat itulah langsung mewawancarainya."

Selain hasil wawancara tentang teknis seleksi terhadap kepala sekolah, ada pula hasil wawancara yang dikemukakan oleh kepala tata usaha terhadap teknis seleksi tenaga pendidik mengungkapkan bahwa:

"Teknis seleksi dilakukan secara langsung yang harus membawa lamaran kerja orang yang bersangkutan dan akan diwawancarai oleh kepala sekolah."

Dari hasil wawancara yang telah diungkapkan di atas terhadap proses seleksi maka penulis dapat menganalisis sekolah dalam melakukan proses seleksi pelamar atau tenaga pendidik yang baru harus mengantarkan berkas lamarannya sendiri, karena setelah berkas dikumpulkan kepala sekolah akan melakukan teknis wawancara terhadap tenaga pendidik yang baru setelah itu sekolah dalam hal ini kepala sekolah akan menentukan diterima atau tidaknya tenaga pendidik yang baru melamar, setelah wawancara akan dihubungi kembali oleh pihak sekolah untuk mendapat jawaban atas proses seleksi.

\section{Orientasi tenaga pendidik}

Orientasi adalah pengenalan dan adaptasi terhadap sebuah situasi atau lingkungan baru (Nurul Ulfatin, 2016: 66). Orientasi merupakan bagian dari proses pengelolaan tenaga pendidik dimana proses orientasi ini penting bagi tenaga pendidik yang baru untuk mengenal lingkungan tempat bekerjanya yang baru setelah diterima atau lulus dalam tahap seleksi maka orientasi tenaga pendidik perlu agar mampu beradaptasi dengan 
lingkungan kerjanya yang baru, tentang tugas-tugas baru yang harus dikerjakan. Karena orientasi merupakan proses dari pengelolaan untuk masa pengenalan terhadap pegawai baru/tenaga pendidik sehingga mengenal lingkungan kerjanya. Adakah bentuk orientasi tenaga pendidik di sekolah, Sebagaimana yang diungkapkan oleh kepala sekolah dalam wawancara mengungkapkan:

"Ada, pada saat upacara bendera guru baru diperkenalkan dan dijadikan pembina upacara dan masa orientasi selama 2 minggu."

Selain dari hasil wawancara terhadap kepala sekolah tentang adakah bentuk orientasi tenaga pendidik, salah satu guru yang diwawancarai mengungkapkan bahwa.

"Ada, tetapi dalam waktu yang relatif singkat, Itu berdasarkan waktu guru ada yang masuk pada tahun ajaran baru, ada juga di pertengahan semester jadi waktunya tidak ditentukan."

Dari hasil wawancara yang telah diungkapkan di atas mengenai orientasi tenaga pendidik maka penulis dapat menganalisis bahwa proses orientasi tenaga pendidik di sekolah sudah ada, namun hanya dilakukan dalam waktu yang sikat dan bentuknya hanya seperti tenaga pendidik baru menjadi pembina upacara dengan harapan mampu beradaptasi dengan lingkungan kerja dan mampu mengenal sesama tenaga pendidik dan murid-murid di sekolah. Sehingga proses orientasi yang dilakukan oleh sekolah khususnya kepala sekolah sudah berjalan dengan baik walaupun dalam waktu yang relatif singkat. Namun dari hasil dokumentasi dan pengamatan langsung maka proses orientasi tenga pendidik di sekolah belum maksimal karena tenaga pendidik yang baru diterima tidak diberikan banyak waktu untuk beradaptasi, hal ini dibuktikan dengan tidak adanya masa pengenalan hanya melalui upacara setiap hari senin tenaga pendidik dijadikan pembina upacara tanpa adanya proses pengenalan baik kondisi sekolah, siswa serta tugas yang akan dikerjakan. Hal ini menyebabkan proses orientasi tenaga pendidik belum berjalan secara maksimal.

\section{Penempatan tenaga pendidik}

Penempatan tenaga pendidik/ pegawai dapat diartikan sebagai tindak lanjut dari proses seleksi tenaga pendidik, yaitu menempatkan tenaga pendidik yang diterima pada jabatan/pekerjaan yang 
membutuhkannya (Yuniarsih Tjutju, 2011: 155). Penempatan tenaga pendidik merupakan rangkaian dalam proses pengelolaan tenaga pendidik dimana proses penempatan merupakan tindak lanjut dari tahap seleksi dan orientasi. Dalam proses penempatan tenaga pendidik yang harus diperhatikan adalah latar belakang pendidikan tenaga pendidik, kinerja tenaga pendidik serta keterampilan tenaga pendidik dalam melaksanakan tugas yang telah diberikan. Adapun proses penempatan tenaga pendidik yang dilakukan sekolah sebagaimana yang diungkapkan oleh kepala sekolah dalam hasil wawancara mengungkapkan:

"Intinya pihak sekolah dalam hal ini yayasan dan kepala sekolah menerima tenaga pendidik semuanya hampir S1 kecuali (Pak Wisa) yang guru olahraga alumni S1 Janasiasah serta terdapat 2 guru yang tamatan SMA."

Di dalam proses penempatan tenaga pendidik ada pula hasil wawancara yang dilakukan terhadap salah satu guru yang mengungkapkan bahwa:

"Untuk penempatan tenaga pendidik sejauh ini sudah sesuai dengan latar pendidikan yang harus S1."

Selain proses penempatan, terdapat juga faktor-faktor yang harus diperhatikan dalam penempatan tenaga pendidik di sekolah, hal ini juga yang disampaikan oleh kepala sekolah dalam hasil wawancara yang mengungkapkan bahwa:

"Latar belakang pendidikan, pengalaman kerja, tempat atau alamat tinggal tenaga pendidik."

Adapun hasil observasi yang dilakukan peneliti di sekolah tentang proses penugasan atau penempatan tenaga pendidik sebagai berikut:

"hasil pengamatan peneliti tentang penugasan atau penempatan tenaga pendidik yang dilakukan oleh kepala sekolah sudah sesuai dengan persyaratan yang harus minimal berpendidikan strata 1 (S1) namun sejauh pengamatan yang dilakukan peneliti di lapangan ada guru yang belum S1 atau hanya tamatan SMA, serta terdapat guru yang mengajar tidak sesuai dengan latar belakang pendidikannya seperti guru olahraga yang berlatar belakang pendidikan Janasiasah (S1 Fakultas Syariah) dalam penempatannya menjadi guru 
olahraga di sekolah." (Hasil observasi).

Dari hasil wawancara dan observasi yang dilakukan terhadap proses penempatan tenaga pendidik di sekolah, maka penulis dapat menganalisis bahwa, proses penempatan tenaga pendidik yang dilakukan oleh kepala sekolah pertama dalam penempatan tenaga pendidik mayoritas sudah strata 1 (S1), namun ada tenaga pendidik yang sudah S1 tetapi tidak ditempatkan sesuai latar belakang keilmuannya seperti pak Wisa dengan latar belakang pendidikan syariah yang ditempatkan sebagai guru olah raga, serta ada 3 tenaga pendidik yang masih berlatar belakang SMA yang ditempatkan oleh kepala sekolah kurang maksimal dan tidak sesuai teori dimana proses penempatan yang baik tenaga pendidik harus ditempatkan sesuai latar belakang keilmuan dan syarat menjadi guru yang berpendidikan strata 1 (S1) sehingga proses penempatan di sekolah masih kurang maksimal.

Kemudian dalam hasil wawancara yang dilakukan dengan kepala sekolah adapun faktor-faktor penempatan tenaga pendidik, kepala sekolah melihat dari faktor latar belakang pendidikan yang hampir seluruhnya strata 1 (S1) kemudian kepala sekolah melihat dari pengalaman kerja tenaga pendidik yang sudah pernah mengajar sebelumnya serta melihat dari letak tempat tinggal tenaga pendidik itu sendiri yang harus dekat dengan sekolah sehingga tenaga pendidik tidak terlambat datang ke sekolah, jadi proses pembelajaran yang dilakukan tenaga pendidik dapat berjalan sesuai dengan jam waktu masuk sekolah dan jam mengajar tenaga pendidik itu sendiri. Fakta di lapangan dari proses dokumentasi dan observasi tenaga pendidik banyak yang belum memiliki pengalaman belajar hal ini dibuktikan dari masa kerja tenaga pendidik dengan ijazah tahun kelulusannya, kemudian untuk tempat tinggal tenaga pendidik jauh dari sekolah hal ini sesuai dengan hasil biodata tempat tinggal tenga pendidik yang diperoleh dari dokumentasi.

\section{Evaluasi tenaga pendidik}

Evaluasi sering juga disamakan artinya dengan penilaian, yaitu suatu proses menetapkan nilai, kualitas atau status dari suatu objek, orang atau benda. Evaluasi kinerja merupakan penerapan riset evaluasi dalam bidang manajemen sumber daya pendidikan (Nurul Ulfatin, 2016: 150-154). Salah satu proses pengelolaan tenaga 
pendidik yang sangat penting yang terakhir adalah evaluasi tenaga pendidik, dimana evaluasi tenaga pendidik sangat penting dilakukan oleh sekolah khususnya kepala sekolah terhadap tenaga pendidik untuk menilai kinerja yang telah dilakukan tenaga pendidik sehingga dapat meningkatkan lagi kinerja tenaga pendidik dalam proses pembelajaran di sekolah, sehingga dengan adanya evaluasi tenaga pendidik menjadi bahan penilaian kepala sekolah terhadap tenaga pendidik ada. Adanya kegiatan evaluasi tenaga pendidik di sekolah seperti yang disampaikan kepala sekolah dalam hasil wawancara mengungkapkan bahwa:

"Ada setiap 1 tahun 2 kali dengan mensupervisi guru. 1x pada awal tahun ajaran baru (bulan 10/Oktober) dan semester genap pertengahan sekitar bulan (4/April)."

Adapun bentuk-bentuk evalusai yang dilakukan di sekolah seperti yang disampaikan salah seorang guru dalam hasil wawancara mengungkapkan bahwa:

"Bentuk evaluasi yang dilakukan oleh pihak sekolah diadakannya rapat guru serta ada juga yang berbentuk tes dan non tes serta pengawasan dari kepala sekolah."
Adapun hasil observasi yang dilakukan peneliti di sekolah tentang proses evaluasi tenaga pendidik sebagai berikut:

"Adapun hasil pengamatan peneliti selama magang di sekolah dari awal bulan Agustus sampai awal bulan November. Evaluasi tenaga pendidik yang dilakukan kepala sekolah berupa pengawasan langsung di dalam kelas terhadap kinerja guru saat menyampaikan proses pembelajaran, selain pengawasan yang dilakukan kepala sekolah sejauh pengamatan yang dilakukan peneliti. Kepala sekolah juga melakukan rapat guru di akhir bulan dengan memulangkan murid lebih cepat biasanya pada hari sabtu diakhir bulan semua guru dirapatkan oleh kepala sekolah guna mengevaluasi kinerja tenaga pendidik serta menyampaikan masukan kepada guru terhadap hasil evaluasi yang sudah dilakukan seperti metode mengajar guru serta bahan yang diajarkan guru harus lebih sesuai dengan arahan dari kepala sekolah." (Hasil observasi).

Dari hasil wawancara serta hasil observasi yang telah dikemukakan di atas maka peneliti dapat menganalisis proses evaluasi tenaga pendidik di sekolah yang dilakukan oleh kepala 
sekolah sendiri memang ada 1 (satu) tahun sekali dengan cara mensupervisi tenaga pendidik yang mana proses evaluasi dilakukan pada awal tahun ajaran baru dan di pertengahan semester genap kepala sekolah mengadakan rapat guru membahas serta menilai kinerja guru selama melakukan proses pembelajaran.

Adapun bentuk evaluasi tenga pendidik yang dilakukan oleh kepala sekolah dengan melakukan pengawasan kepada guru, serta juga dilakukannya proses evaluasi tenaga pendidik dengan bentuk tes dan non tes sehingga kepala sekolah dapat menilai kinerja guru serta dapat menyampaikan hasil evaluasi tenaga pendidik dalam forum rapat guru, tentang hal apa saja yang perlu ditinggkatkan lagi sehingga kinerja guru dapat jauh lebih baik kedepannya.

\section{Faktor Pendukung dan} Penghambat Implementasi Pengelolaan Tenaga Pendidik di MI Az-Zahir Palembang

Dalam pelaksanaan pengelolaan tenaga pendidik di suatu lembaga pendidikan tentunya memiliki faktor pendukung dan penghambat. Faktor pendukung merupakan hal yang penting dalam proses pengelolaan tenaga pendidik terutama bagi pihak lembaga pendidikan/sekolah.

Adapun faktor pendukung dan penghambat dalam pengelolaan tenaga pendidik berdasarkan hasil penelitian yang telah dilaksanakan sebagai berikut:

\section{a. Faktor Pendukung}

Faktor pendukung dalam pengelolaan tenaga pendidik ialah a). Kompetensi/kemampuan kepala sekolah mengelola tenaga pendidik; b). Kompentensi tenaga pendidik yang sesuai dengan bidang keilmuannya, c). Sarana dan prasarana yang lengkap; d). Keuangan/pembiayaan; dan e). Peran serta masyarakat dalam pengelolaan tenaga pendidik. Adapaun hasil wawancara dengan kepala sekolah tentang faktor apa saja yang mendukung pengelolaan tenaga pendidik mengungkakan bahwa:

"Faktor pendukungnya mayoritas tenaga pendidik di sekolah ini semuanya sudah strata 1 , sarana dan prasarana di sekolah sudah cukup memadai bagi proses pembelajaran, adanya komite sekolah yang ikut serta dalam rapat sekolah, adanya dana bantuan dari pemerintah seperti BOS dalam menunjang pengelolaan di sekolah." 
Dari hasil wawancara yang telah dilakukan dengan kepala sekolah maka penulis dapat melakukan analisis terhadap faktor pendukung pengelolaan tenaga pendidik bahwa faktor pendukung pengelolaan tenaga pendidik MI Az-Zahir Palembang.

1) Kompetensi/Kemampuan Kepala Sekolah

Kompetensi kepala sekolah menurut Sagala (2009:126) menyatakan bahwa kompetensi adalah seperangkat pengetahuan, keterampilan, dan prilaku yang harus dimiliki oleh kepala sekolah dalam menjalankan tugas dan tanggung jawabnya. menurut peraturan Menteri Pendidikan Nasional Republik Indonesia Nomor 13 Tahun 2007, tentang standar kepala sekolah/madrasah bahwa kepala sekolah harus memiliki standar kompetensi kepribadian, kompetensi manajerial, kompetensi kewirausahaan, kompetensi supervisi, dan kompetensi sosial.

Dari hasil wawancara dan observasi yang dilakukan peneliti, kepala sekolah dalam mengelola tenaga pendidik sudah cukup baik dengan melibatkan guru dalam proses perencanaan pembelajaran dalam rapat dewan guru, adanya diklat dan workshop yang dilakukan kepala sekolah dengan mengirim guru untuk mengikuti diklat dan workshop. Selain itu kompetensi kepala sekolah yang telah sarjana $\mathrm{S} 1$ dengan berlatar belakang pendidikan dan sudah lebih dari 5 tahun mengajar menjadi faktor pendukung dalam melaksanakan pengelolaan tenaga pendidik di MI AzZahir Palembang.

2) Kompetensi Tenaga Pendidik Kompetensi tenaga pendidik dalam hal ini guru menurut Majid (2005: 6) menjelaskan kompetensi yang dimiliki oleh setiap guru akan menunjukan kualitas guru dalam mengajar, kompetensi tersebut akan terwujud dalam bentuk penguasaan pengetahuan dan profesional dalam menjalankan fungsinya sebagai guru. Dalam Pasal 28 Ayat 3 Peraturan Pemerintah No 19 Tahun 2005 tentang Standar Nasional Pendidikan secara tegas dinyatakan bahwa ada empat kompetensi yang harus dimiliki oleh guru sebagai agen pembelajaran yaitu kompetensi pedagogik, kepribadian, profesional, dan kompetensi sosial.

Dari hasil wawancara yang telah dilakukan di atas, maka penulis dapat menganalisis faktor pendukung pengelolaan tenaga pendidik melihat dari kompetensi guru yang didapat melalui hasil dokumentasi dari total 18 guru hampir semuanya strata 1 (S1), memiliki kepribadian yang baik 
dibuktikan dengan hasil wawancara dengan kepala sekolah bahwa guru yang diterima harus memiliki kelakukan baik dan tidak terlibat tindak pidana atau kejahatan.

\section{3) Sarana dan Prasarana}

Sarana dan prasarana menurut E. Mulyasa adalah fasilitas yang secara tidak langsung menunjang jalannya proses pendidikan atau pengajaran seperti halaman, kebun, taman sekolah, jalan menuju sekolah. Sedangkan sarana pendidikan digunakan langsung dalam proses pendidikan di sekolah contohnya. Gedung sekolah, ruangan, meja, kursi, alat peraga, dan lain-lain.

Dari hasil observasi serta pengamatan penulis terhadap sarana dan prasarana di MI Az-Zahir sudah cukup memadai dengan adanya jalan yang sudah diaspal untuk menuju ke sekolah, sudah adanya perpustakaan, ruangan belajar yang terdapat 6 lokal/ruangan kelas, terdapat lapangan di sekolah untuk sarana olahraga dan upacara, adanya ruang guru, ruang kepala sekolah yang terpisah dengan ruang guru, papan tulis di setiap ruangan kelas serta meja dan kursi belajar yang memadai menjadi faktor pendukung pengelolaan di sekolah.
4) Keuangan/Pembiayaan

Pengelolaan keuangan/pembiayaan menurut Kamus Besar Bahasa Indonesia artinya penggunaan sumber daya secara efektif dan efesien, sedangkan pengelolaan keuangan adalah sumber daya yang diterima yang akan dipergunakan untuk penyelenggaraan pendidikan. Adapun sumber-sumber keuangan yang diperoleh sekolah melalui, dana dari pemerintah, dana dari orang tua siswa, dana dari masyarakat, dana dari alumni sekolah dan dana kewirausahaan yang dimiiki sekolah.

Dari hasil wawancara yang dilakukan dengan kepala sekolah faktor pendukung pengelolaan tenaga pendidik, maka penulis menganalisis di sekolah adanya keuangan atau sumber dana dari bantuan pemerintah seperti dana bos untuk membayar gaji tenaga pendidik, dana dari orang tua siswa seperti uang SPP, bantuan dari kepala yayasan yang berupa dana pribadi sehingga mendukung proses pengelolaan tenaga pendidik. Pengadaan perlengkapan pembelajaran serta melengkapi sarana dan prasarana di sekolah.

5) Komite Sekolah

Komite sekolah menurut keputusan Menteri Pendidikan 
Nasional Nomor: 044/U/202, komite sekolah merupakan sebuah badan mandiri yang mewadahi peran serta masyarakat dalam rangka meningkatkan mutu, pemerataan, dan efesiensi pengelolaan pendidikan di satuan pendidikan baik pada pendidikan prasekolah, jalur pendidikan sekolah maupun jalur pendidikan luar sekolah. Dibentuknya komite sekolah dimaksudkan agar adanya suatu organisasi masyarakat yang mempunyai komitmen dan loyalitas serta peduli terhadap peningkatan kualitas sekolah.

Dari hasil wawancara di atas dan hasil dokumentasi di sekolah terhadap faktor pendukung pengelolaan tenaga pendidik, maka penulis menganalisis bahwa sekolah telah mempunyai komite sekolah yang diketuai oleh kepala yayasan serta melibatkan orang tua siswa dalam proses pengelolaan tenaga pendidik guna mendukung proses pengelolaan pendidikan sehinga dapat mencapai tujuan dan visi dan misi yang telah ditetapkan oleh sekolah.

\section{b. Faktor Penghambat}

Selain faktor pendukung dalam pengelolaan tenaga pendidik terdapat pula fakor penghambat pengelolaan tenaga pendidik yang berupa. a).
Kurang mampunya kepala sekolah dalam pengelolaan tenaga pendidik serta pengembangan potensi tenaga pendidik; b). Kompetensi tenaga pendidik yang belum sesuai dengan kebutuhan sekolah; c) sarana dan prasarana yang belum lengkap; d). Kurangnya peran serta masyarakat dalam pengelolaan pendidikan serta fungsinya sebagai komite sekolah; dan e). Pembiayaan/keuangan menjadi faktor penghambat. Seperti yang dikemukakan oleh kepala sekolah dalam hasil wawancara yang menyebutkan faktor penghambat pengelolaan tenaga pendidik mengungkapkan bahwa:

"Hampir sama seperti faktor pendukung, kalau faktor penghambatnya walaupun mayoritas strata 1 tetapi masih ada tenaga pendidik yang SMA, sarana dan prasarana yang belum terpenuhi seperti ruang kelas yang belum ditambah, rusaknya kursi dan meja di beberapa ruangan, minimnya dana serta terhambatnya dana yang cair dari pemerintah, faktor lainnya ialah masyarakat yang kurang faham tentang fungsinya sebagai komite sekolah."

Dari hasil wawancara di atas dan observasi yang dilakukan peneliti, maka peneliti dapat menganalisis 
faktor penghambat dalam pengelolaan tenaga pendidik di MI Az-Zahir Palembang berupa:

1) Kurang mampunya kepala sekolah dalam mengelola tenaga pendidik

Sama seperti faktor pendukung, jika kepala sekolah memiliki kompetensi/kemampuan yang baik, maka faktor penghambat pengelolaan tenaga pendidik, kepala sekolah yang tidak memiliki kompetensi manajerial yang baik. Hal ini disebabkan kurang mampunya kepala sekolah dalam mengelola tenaga pendidik serta pengembangan tenaga pendidik, hal ini dibuktikan dengan lemahnya pengawasan kepala sekolah terhadap tenaga pendidik dengan masih adanya tenaga pendidik yang masih berpendidikan terakhir SMA ada 3 orang guru, masih adanya guru yang mengajar tidak sesuai dengan latar belakang keilmuannya seperti guru olahraga yang memiliki latar belakang S1 Fakultas Syariah Jurusan Janasiasah, dan kurangnya perhatian kepala sekolah terhadap pengembangan tenaga pendidik dengan jarangnya tenaga pendidik dikirim mengikuti pelatihan, seminar dan workshop pendidikan sehingga menjadi faktor penghambat pengelolaan tenaga pendidik.
2) Kompetensi tenaga pendidik yang tidak sesuai kebutuhan sekolah

Salah satu kompetensi yang harus dimiliki tenaga pendidik ialah kompetensi profesional, maka dalam hal ini yang menjadi faktor penghambat pengelolan tenaga pendidik di MI Az-Zahir masih terdapat kompetensi tenaga pendidik yang tidak sesuai dengan kebutuhan sekolah seperti masih adanya guru yang tidak berkompeten dengan latar belakang pendidikannya seperti guru olahraga yang mengajar berlatar belakang pendidikan fakultas Syariah, masih adanya tenaga pendidik yang mengajar hanya tamatan SMA yaitu 3 orang dari total 18 orang tenaga pendidik, masih adanya rangkap jabatan yang dimiliki guru seperti kepala perpustakaan yang merangkap menjadi tenaga pendidik, tenaga pendidik yang merangkap menjadi Tata Usaha sehingga menghambat proses pengelolaan tenaga pendidik dalam mencapai visi dan misi serta tujuan yang telah ditetapkan oleh sekolah.

3) Sarana dan prasara yang belum lengkap

Salah satu faktor penghambat pengelolaan tenaga pendidik di 
sekolah kurangnya sarana dan prasarana di MI Az-Zahir, dari hasil observasi yang dilakukan peneliti bahwa faktor penghambat di sekolah seperti perpustakaan yang masih bercampur dengan kantor sekolah, kurangnya ruangan kelas yang hanya memiliki 6 lokal dan setiap lokal dibagi menjadi 2 kelas, dari total kurang lebih 310 siswa dari kelas 1-6 dari data dokumentasi.

Keadaan lapangan yang tidak terlalu besar, di lantai 2 masih ada lantai yang belum di keramik sehingga ruangan kelas berdebu mengganggu proses pembelajaran, terdapat kursi dan meja yang sudah lama dan tetap dipakai di dalam kelas, kurangnya perawatan sarana dan prasarana oleh pihak sekolah, kurang mudahnya akses ke sekolah karena jauh dari jalan raya dan terletak di perkampungan rumah warga, sehingga menjadi faktor penghambat pengelolaan tenaga pendidik dalam menuju akses ke sekolah.

4) Kurangnya peran serta masyarakat

Terdapat faktor penghambat pengelolaan tenaga pendidik di sekolah dari hasil wawancara di atas serta hasil dokumentasi penulis dapat menganalisis bahwa kurangnya peran serta masyarakat/komite sekolah dalam pengelolaan tenaga pendidik. Hal ini disebabkan karena kurang dilibatkannya komite sekolah dalam proses pengelolaan, ketidakpahaman orang tua siswa tentang tugas dan fungsinya sebaga komite sekolah, kurangnya sosialisasi oleh sekolah tentang rencana sekolah sehingga partisipasi masyrakat terhadap sekolah sangat kurang, sekolah hanya membentuk komite sekolah yang diketuai oleh kepala yayasan namun bukti dilapangan peran serta masyarakat dalam pengelolaan pendidikan masih sangat kurang, jarang dilibatkan dalam proses dan penentuan tujuan dan visi misi sekolah.

5) Pembiayaan/keuangan

Salah satu dari fungsi pengelolaan tenaga pendidik terdapat fakor pembiayaan/keuangan sama seperti halnya yang telah diungkap di atas tentang pengertian pembiayaan pendidikan, yaitu sumber daya yang diterima untuk penyelenggaraan pendidikan. Adapun sumber dana yang diterima oleh sekolah melalui, sumber dana dari pemerintah, orang tua siswa, masyarakat, alumni sekolah dan dana kewirausahaan sekolah. Adapun proses pembiayaan sekolah 
dari tahap perencanaan anggaran sampai evaluasi pembiayaan di sekolah.

Faktor yang menghambat pembiayaan di sekolah dari hasil wawancara dengan kepala sekolah dan hasil observasi di lapangan yang dilakukan peneliti dapat menganalisis bahwa kurangnya perencanaan pembiayaan di sekolah. Hal ini dibuktikan dengan kurangnya sarana dan prasarana di sekolah, tidak tepatnya penggunaan dana sekolah dalam pengadaan barang untuk keperluan sekolah. Kurangnya kinerja bendahara dalam menyusun anggaran sehingga dana yang didapat oleh sekolah minim, hal ini dibuktikan dari hasil pengamatan selama magang, bendahara sekolah kurang cekatan dalam mengurus dana sekolah, kurangya pembuatan proposal pengajuan bantuan baik dipihak swasta maupun dinas terkait dan tidak adanya keterbukaan pengelolaan keuangan sekolah sehingga kurangnya partisipasi masyarakat dalam pembiayaan pengelolaan di sekolah. Terlambatnya dana BOS sehingga menghambat proses operasional sekolah seperti gaji tenaga pendidik, serta pengadaan sarana dan prasarana, dan ketidakmampuan bendahara dalam melakukan perencanaan keuangan seperti pengadaan barang.

\section{E. KESIMPULAN}

Setelah memperhatikan hasil analisis data yang terkumpul dari hasil wawancara, dokumentasi dan observasi tentang implementasi tenaga pendidik dapat disimpulkan bahwa:

1. Implementasi tenaga pendidik di Ml Az-Zahir Palembang dari proses perencanaan, rekrutmen, seleksi, orientasi, penempatan, dan evaluasi tenaga pendidik sudah cukup baik. Karena sekolah telah melakukan proses perencanaan tenaga pendidik sampai evaluasi tenaga pendidik, namun kurangnya pengawasan yang dilakukan kepala sekolah masih ditemukan tenaga pendidik yang mengajar bukan pada keilmuannya serta masih ada guru yang hanya tamatan SMA, sehingga proses implementasi tenaga pendidik belum maksimal.

2. Faktor yang mempengaruhi implementasi tenaga pendidik berupa faktor pendukung dan penghambat. Faktor pendukung yaitu kemampuan kepala sekolah yang baik, kompetensi tenaga pendidik yang sesuai dengan bidang keilmuannya, sarana dan prasarana yang lengkap, 
pembiayaan yang memadai, dan komite sekolah yang berperan aktif. Sedangkan faktor penghambat implementasi tenaga pendidik yaitu kurang mampunya kepala sekolah dalam melakukan pengelolaan tenaga pendidik, kompetensi tenaga pendidik yang tidak sesuai dengan keilmuannya dan kebutuhan sekolah, sarana dan prasarana yang belum lengkap, kurangnya peran serta masyarakat dalam pengelolaan tenaga pendidik, dan pengelolaan pembiayaan keuangan yang belum maksimal.

\section{DAFTAR PUSTAKA}

Emzir. (2011). Metode Penelitian Pendidikan. Jakarta: PT Raja Grafindo.

Hasil wawancara dengan Pak A. Asymawi, S.Pd.I selaku kepala sekolah MI Az-Zahir Palembang.

Mahdi, A. dan Mujahidin. (2014). Panduan Penelitian Praktis untuk Menyusun Skripsi. Tesis dan Disertasi. Bandung: Alfabeta.
Nurul, U. (2016). Manajemen Sumber Daya Manusia Bidang Pendidikan. Jakarta: PT RajaGrafindo Persada.

Ramayulis. (2013). Profesi dan Etika Keguruan. Jakarta: Kalam Mulia.

Sarwoto. (2000). Dasar-Dasar Organisasi dan Manajemen. Jakarta: Ghalia Indonesia.

Syaifuddin, A. (1998). Metode Penelitian. Yogyakarta: Pustaka Pelajar.

Sugiyono. (2013). Cara Mudah Menyusun Skripsi, Tesis dan Disertasi. Bandung: Alfabeta.

Sugiyono. (2010). Metode Penelitian (Pendekatan Kuantitatif, Kualitatif, dan RAD). Bandung: Alfabeta.

Siagian, S.P. (2013). Manajemen Sumber Daya Manusia. Jakarta: PT Bumi Aksara.

Tjutju, Y. (2011). Manajemen Sumber Daya Manusia. Bandung: CV ALFABETA. 